\title{
RHINOSPORIDIOSIS IN THREE NORTHERN DISTRICTS OF WEST BENGAL AND TWO ADJACENT DISTRICTS OF BIHAR - STUDY OF 116 CASES
}

\author{
Anupam Saha1, Mala Mukherjee ${ }^{2}$, Bijayanta Sircar ${ }^{3}$ \\ 1 Professor, Department of Pathology, MGM Medical College and LSK Hospital, Kishanganj, Bihar. \\ ${ }^{2}$ Assistant Professor, Department of Pathology, MGM Medical College and LSK Hospital, Kishanganj, Bihar. \\ ${ }^{3}$ M. Phil Scholar, Laboratory of Microbiology and Experimental Medicine, Department of Zoology, University of Gour Banga, Malda.
}

\section{ABSTRACT}

\section{BACKGROUND}

Study of Rhinosporidiosis was done in Northern 3 districts of West Bengal and adjacent two districts of Bihar as there was no such previous study in these regions. In this study, total 116 patients were encountered during about eleven years of period from January 2006 to November 2016.

The aim of this study is to study the incidence and clinicopathological features of this disease in the Northern 3 districts of West Bengal and adjacent two districts of Bihar.

\section{MATERIALS AND METHODS}

Total 116 patients of Rhinosporidiosis were studied during about 11 years of period from January 2006 to November 2016. Extensive clinical history taking and histopathological examination of affected tissue were done.

\section{RESULTS}

Maximum incidence was seen in young adult age group with male predominance. Nose along with nasopharynx was the most common site of involvement followed by ocular and oropharyngeal infection respectively. Two cutaneous lesions were encountered along with nasal involvement. Rhinosporidiosis could be clearly identified in $\mathrm{H}$ and E stain. Sporangia and spores are better identified by special stains like PAS, GMS, Mayer's mucicarmine, Verhoeff's Van Gieson.

\section{CONCLUSION}

Rhinosporidiosis is seen in notable number in this region, having history of taking bath of all patients in stagnant pond water in which cattle and buffaloes are taking bath regularly and the leaves (specially of bamboo trees) are seen floated over the water surface of the pond.

\section{KEYWORDS}

Rhinosporidium Seeberi, Rhinosporidiosis, Histopathological Features.

HOW TO CITE THIS ARTICLE: Saha A, Mukherjee M, Sircar B. Rhinosporidiosis in three northern districts of West Bengal and two adjacent districts of Bihar - study of 116 cases. J. Evolution Med. Dent. Sci. 2017;6(3):155-160, DOI: 10.14260/Jemds/2017/38

\section{BACKGROUND}

Rhinosporidiosis is a chronic granulomatous infection of humans and animals which is non-contagious, sporadic, benign, usually non-fatal with evidence of recurrence after surgical removal. It is caused by organism, Rhinosporidium seeberi, known for more than 120 years. However, there are few problems yet unsolved regarding its phylogeny.1,2 It was first described as a sporozoon by Malbarn in Argentina in 1892 from a nasal polyp of a patient. Seeberi in 1990 first identified the organism as protozoan. In India, the first case was reported by O'Kinealy in 1903 which was observed by him in 1894. In 1923, Asworth labelled it as phycomycete and named the pathogen as Rhinosporidium seeberi by giving description of its morphology and life cycle.2,3 Detailed histology and life cycle of Rhinosporidium seeberi was obtained in the

Financial or Other, Competing Interest: None.

Submission 21-12-2016, Peer Review 03-01-2017,

Acceptance 05-01-2017, Published 07-01-2017.

Corresponding Author:

Dr. Anupam Saha,

Professor, Department of Pathology,

MGM Medical College \& LSK Hospital,

Kishanganj-855107, Bihar, India.

E-mail: dranupamsaha@yahoo.co.in

DOI: $10.14260 /$ jemds $/ 2017 / 38$ article published by Karunaratne. ${ }^{2,4}$ It was reviewed by Arseculertne in 1998.5 In 1999, Herr et al classified the organism from a new clade (DRIPs clade) and named as mesomycetozoea based on molecular biological analysis of 18S rRNA through PCR. 2,6 Recent advances in Rhinosporidiosis and Rhinosporidium seeberi were highlighted by Arseculertne (2002) and Pal et al (2016).7,8

Rhinosporidiosis with global distribution has been reported from 70 countries with highest incidence from India and Srilanka.1,2,8 It is endemic in Kerala,2,9 Tamilnadu,2,10 Orissa,2,11 Chhattisgarh2,12 and parts of the West Bengal.2,13

The nose and nasopharynx are the most common and primary sites of infection comprising of $70 \%$ of cases $1,2,8$ followed by ocular infection in about $10 \%$ of cases. ${ }^{14}$ The rare sites such as maxillary sinus, lips, palate, epiglottis, uvula, tongue, oropharynx, genitals, urethra, rectum, skin and bone have also been observed. $1,2,9,12,15$

\section{Aims and Objectives}

1. The present study has been carried out to evaluate the incidence in three Northern districts of West Bengal (Called as part of North Bengal) and two adjacent districts of Bihar, as there are no previous study regarding Rhinosporidiosis from this region.

2. To study the clinicopathological aspects of Rhinosporidiosis in this region. 


\section{MATERIALS AND METHODS}

We are presenting a total number of 116 cases of Rhinosporidiosis in the Department of Pathology, MGM Medical College, Kishanganj, Bihar during a period of about 11 years from January 2006 to November 2016. The patients were from three Northern districts of West Bengal (Uttar Dinajpur, Dakshin Dinajpur and Malda) and two adjacent districts of Bihar (Kishanganj and Purnia).

Staining of tissue sections was done by haematoxylin and eosin. Special stains like PAS, GMS, Mayer's mucicarmine, Verhoeff's Van Geison were carried out wherever required.

Histopathological sections were studied in detail along with various tissue reactions due to Rhinosporidiosis.

\section{RESULTS}

Most of the patients were of young adult age group. The age of patients ranged from 7 years to 69 years. There was significant male preponderance (Table 1, Chart 1).

\begin{tabular}{|c|c|c|c|c|c|c|c|c|}
\hline $\begin{array}{c}\text { Age Group } \\
\text { (Years) }\end{array}$ & $\begin{array}{c}\text { Upto } \\
\mathbf{1 0}\end{array}$ & $\mathbf{1 1 - 2 0}$ & $\mathbf{2 1 - 3 0}$ & $\mathbf{3 1 - 4 0}$ & $\mathbf{4 1 - 5 0}$ & $\begin{array}{c}\text { Above } \\
\mathbf{5 0}\end{array}$ & Total & $\mathbf{\%}$ \\
\hline Male & 3 & 19 & 35 & 16 & 11 & 5 & 89 & 76.72 \\
\hline Female & 1 & 7 & 13 & 3 & 1 & 2 & 27 & 23.28 \\
\hline Total & $\mathbf{4}$ & $\mathbf{2 6}$ & $\mathbf{4 8}$ & $\mathbf{1 9}$ & $\mathbf{1 2}$ & $\mathbf{7}$ & $\mathbf{1 1 6}$ & $\mathbf{1 0 0}$ \\
\hline \multicolumn{7}{|c|}{ Table 1. Age and Sex Distribution } \\
of 116 Cases of Rhinosporidiosis \\
\hline
\end{tabular}

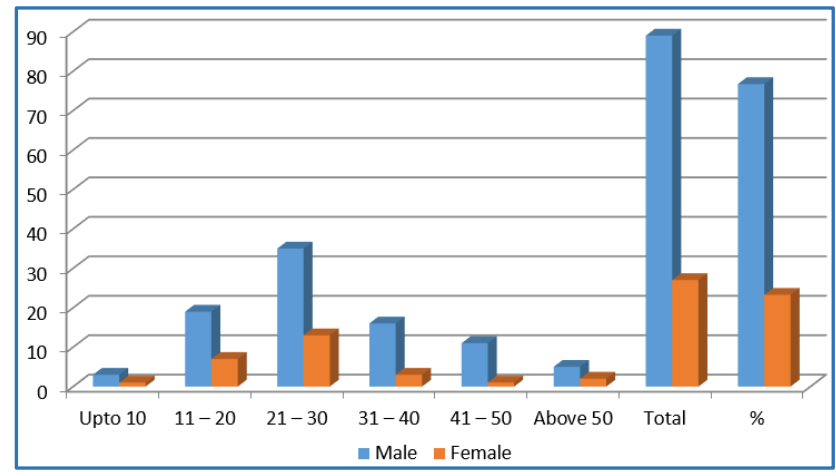

Chart 1. Age and Sex Distribution of 116 Cases of Rhinosporidiosis

(Age group in years)

All patients were from rural areas. Out of 116 patients, 83 were farmers, 19 students and 14 daily manual labourers. The rural students were also engaged in cultivation off and on. All the patients gave history of taking bath in stagnant pond water in which cattles were also bathed regularly. It was also known from the history from the patients that leaves (especially bamboo leaves) are seen floating on the water surface of these ponds, fallen from the bamboo bush nearby the ponds.

Most of the patients represented with nasal obstruction followed by nasal bleeding. The commonest site of Rhinosporidiosis (89.66\%) of our series was nasal region (Figure 1) including both nose and nasopharynx (104 out of 116) followed by 7 cases of ocular Rhinosporidiosis (6.03\%) (Figure 2). Oropharyngeal involvement of Rhinosporidiosis (Figure 3 and 4 ) was seen in 3 cases (2.59\%). Only 2 cases showed skin and subcutaneous tissue involvement along with nasal Rhinosporidiosis (Table 2, Chart 2).

\begin{tabular}{|c|c|c|}
\hline Sites & No & $\mathbf{\%}$ \\
\hline Nasal & $\mathbf{1 0 4}$ & $\mathbf{8 9 . 6 6}$ \\
\hline Nose & 91 & 78.45 \\
\hline Nasopharynx & 13 & 11.21 \\
\hline Ocular & $\mathbf{7}$ & $\mathbf{6 . 0 3}$ \\
\hline Lacrimal sac & 5 & 4.31 \\
\hline Conjunctiva & 2 & 1.72 \\
\hline Oropharyngeal & $\mathbf{3}$ & $\mathbf{2 . 5 9}$ \\
\hline $\begin{array}{c}\text { Skin and subcutaneous tissue } \\
\text { along with nasal involvement }\end{array}$ & 2 & 1.72 \\
\hline \multicolumn{2}{|c|}{$\begin{array}{c}\text { Table 2. Distribution of Sites of } \\
\text { 116 Cases of Rhinosporidiosis }\end{array}$} \\
\hline \multicolumn{2}{|l}{} \\
\hline
\end{tabular}

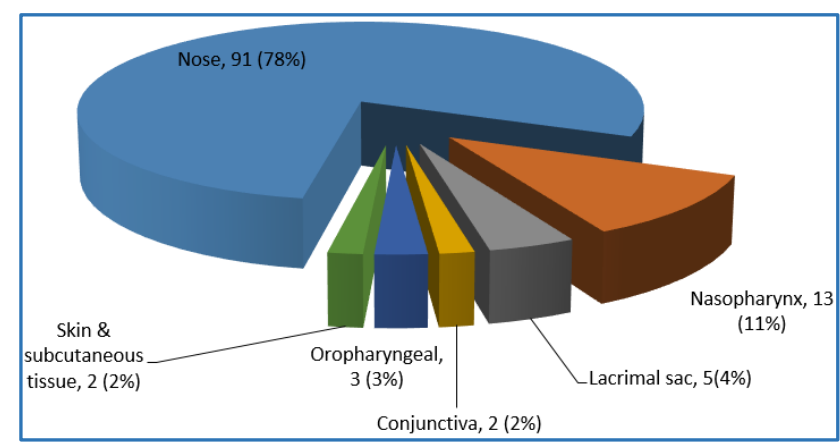

Chart 2. Distribution of Sites of 116 Cases of Rhinosporidiosis

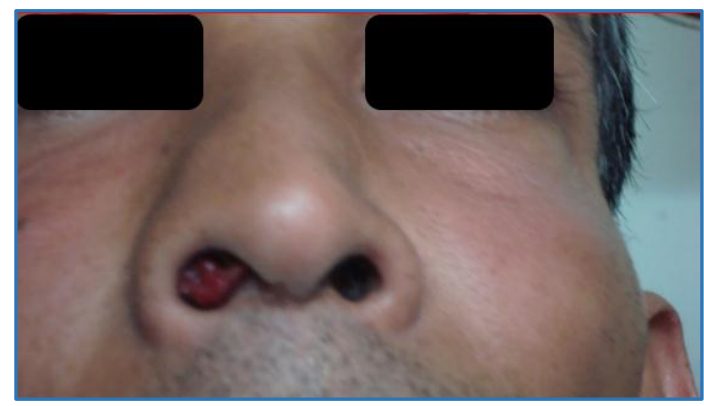

Figure 1. Showing Rhinosporidiosis in Nasal Cavity

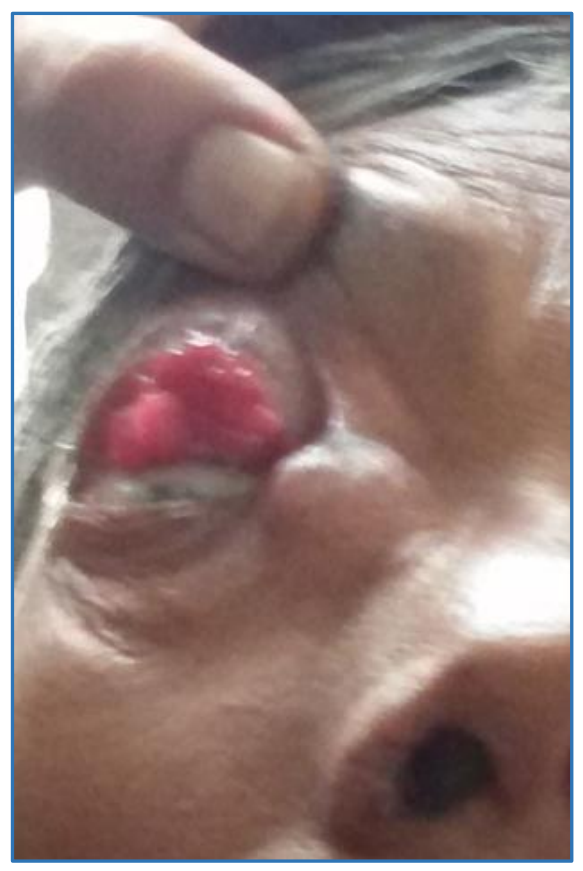

Figure 2. Showing Pedunculated Lesion of Rhinosporidiosis from Conjunctiva 


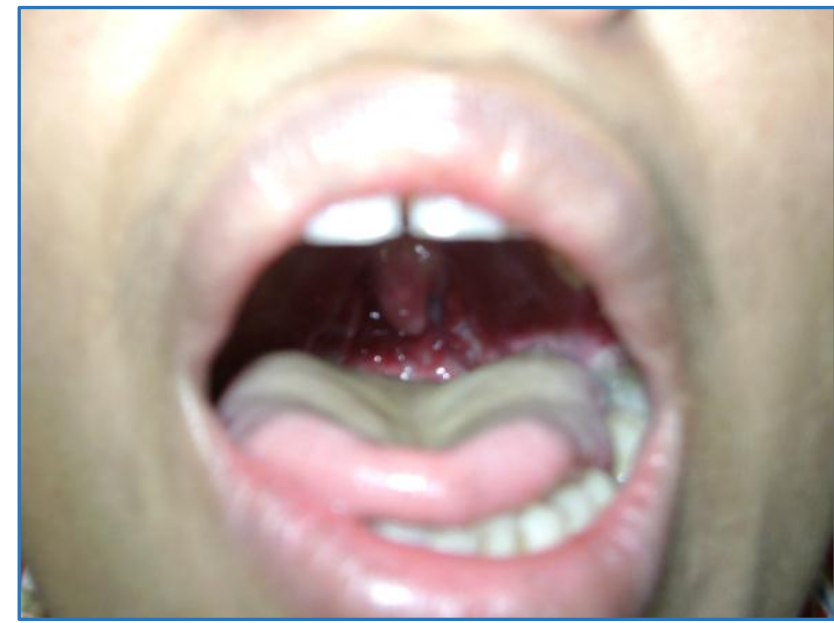

Figure 3. Showing Cauliflower-Like Mass of Rhinosporidiosis in Oropharynx

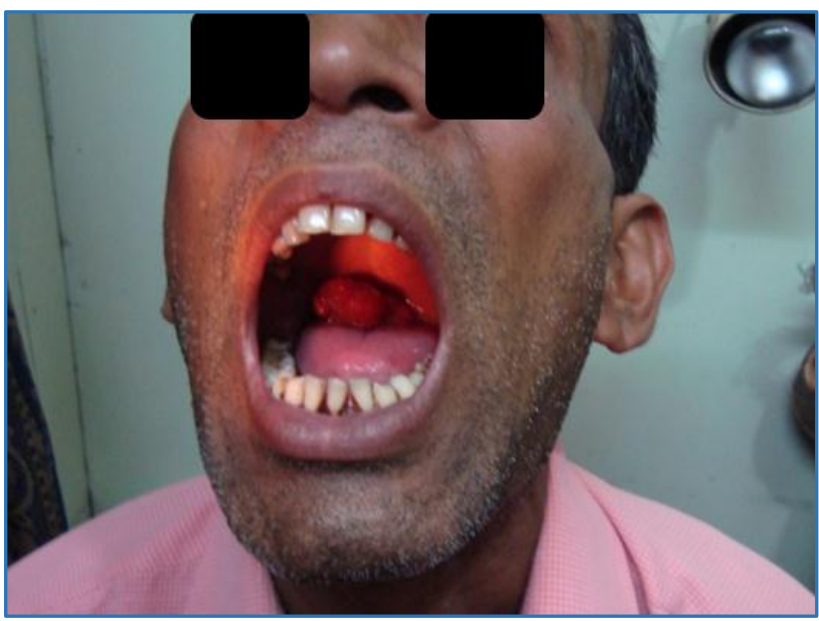

Figure 4. Rhinosporidiosis in Oropharynx

Histopathological Features

The following histopathological features were noted in microscopic examination.

- Papillomatous hyperplasia in 109 cases (93.97\%) (Figure 5).

- Focally ulcerated lining epithelium was noted in 106 cases (91.38\%) (Figure 6).

- $\quad$ Squamous metaplasia in 97 cases (83.62\%) (Figure 6).

- The Sporangia at different stages of maturation were noted. Few were seen at the surface of thinned out epithelium (Figure 6). Large number of sporocysts or sporangia were seen in the stroma (Figure 7). Mature sporangia were of 200 to 300 microns in diameter, walled by double layered envelope (Figure 8).

- The sporocysts were filled with multiple round endospores measuring 10 to 12 microns in diameter (Figure 8).

- Discharging of spores by mature sporocysts was seen in stroma in few cases (Figure 9).

- Elimination of spores from mature sporangium was noted on the surface of the lining epithelium along with transepidermal elimination of sporangium in few cases (Figure 10 and 11).

- Degenerated and empty sporocysts were also seen. (Figure 11).
- Cellular response in the form of lymphoplasmacytic infiltration was noted in 113 cases (Figure 7).

- Mixed inflammatory cell infiltration was noted in 61 cases (Figure 12).

- Micro abscess was noted in 11 cases (Figure 13).

- Granulomatous inflammation was noted in 7 cases (Figure 14).

- Stromal oedema was also noted in almost all cases (Figure 15).

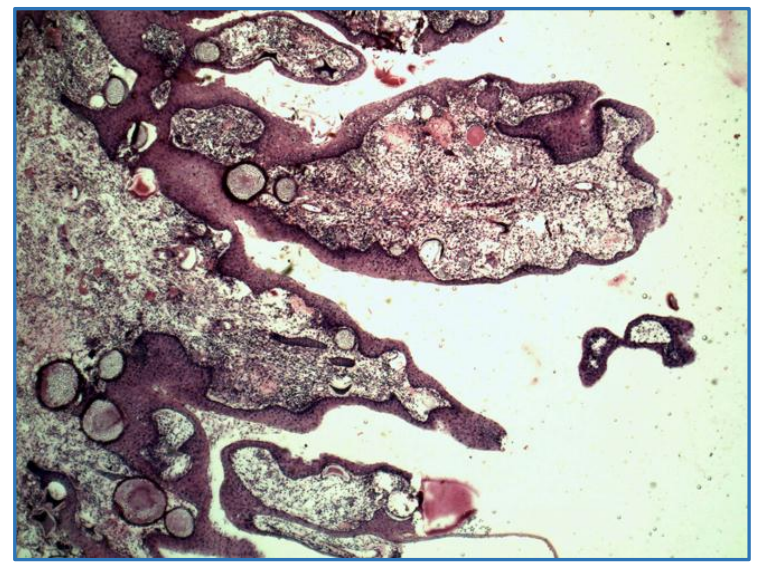

Figure 5. Microphotograph shows Papillomatous Hyperplasia of Lining Epithelium with Multiple Sporangium within the Stroma (H \& E x100)

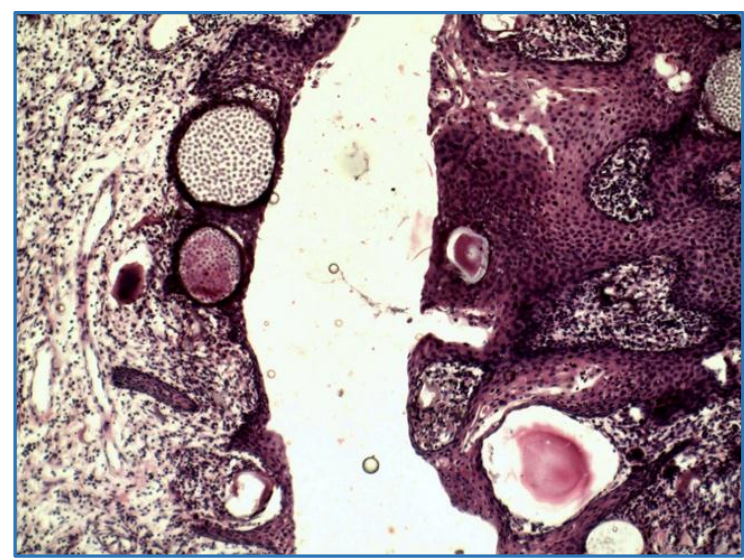

Figure 6. Focally Ulcerated Lining Epithelium with Sporangia at the Surface of Thinned Out Epithelium (Left Side), and Squamous Metaplasia of Lining Epithelium (Right Side) (H \& E x100)

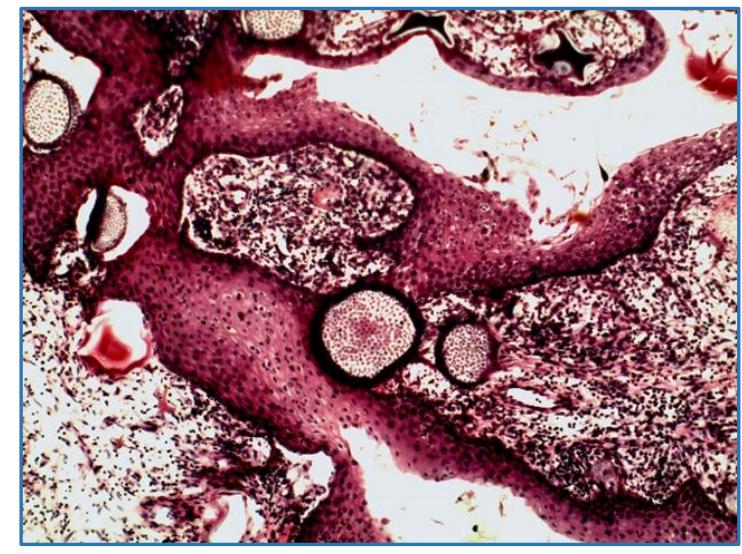

Figure 7. Large Number of Sporocysts or Sporangia are seen in the Stroma (H \& E x100) 


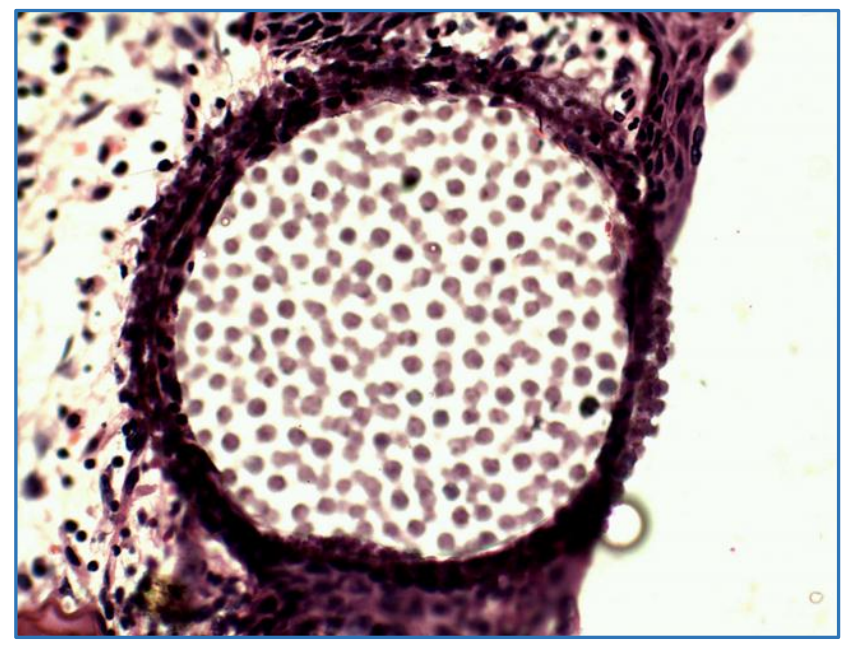

Figure 8. Microphotograph showing Sporocysts are Filled with Multiple Round Endospores (H \& E x400)

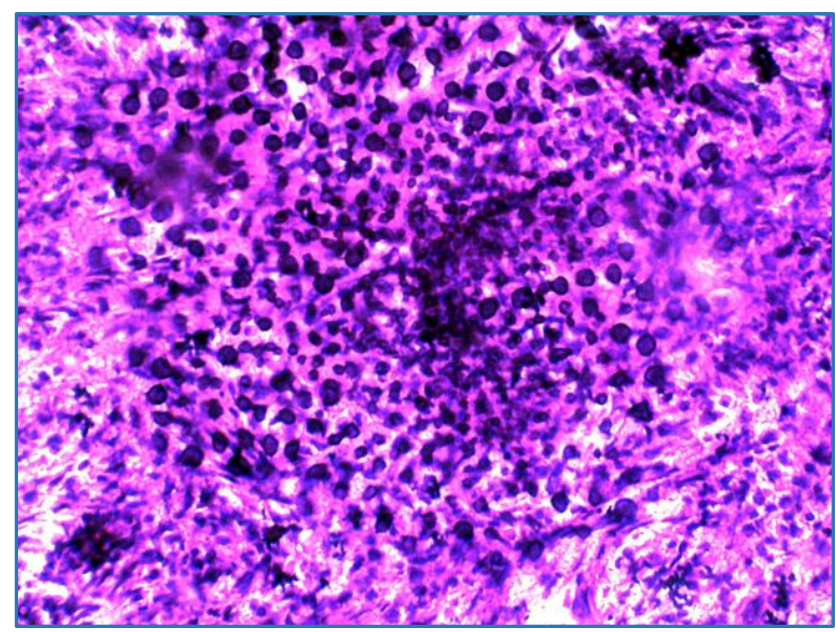

Figure 9. Microphotograph showing Discharging of Spores by Mature Sporocysts in Stroma (H \& E X400)

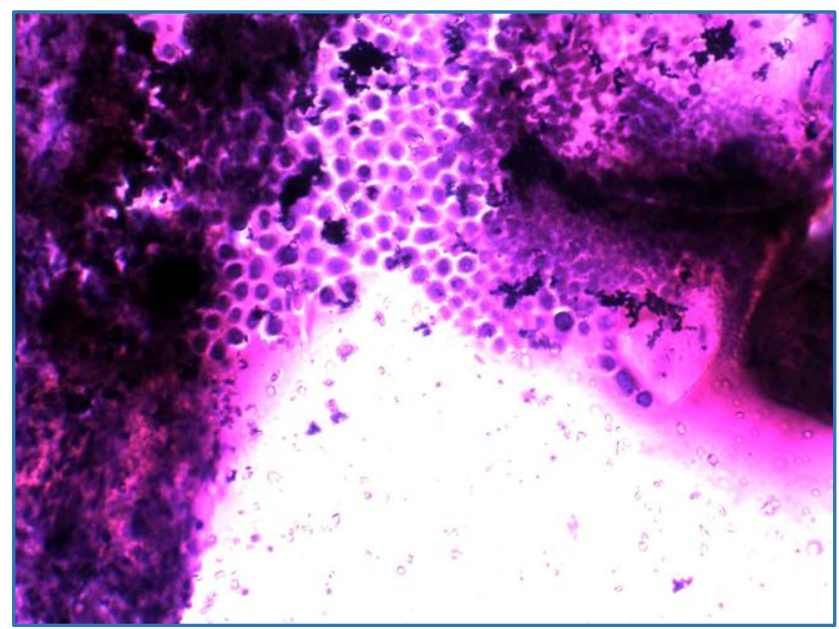

Figure 10. Microphotograph showing

Transepidermal Elimination of Spores (H \& E x400)

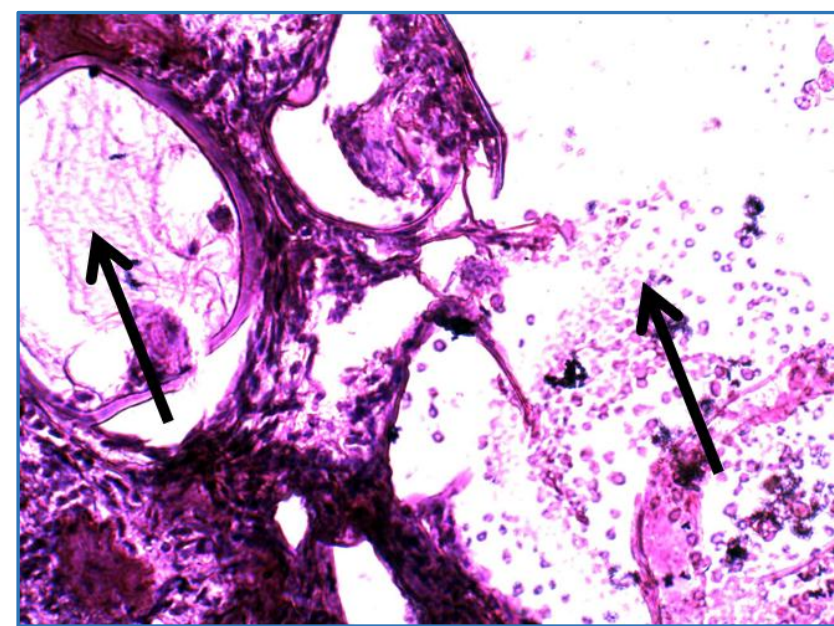

Figure 11. Microphotograph showing Degenerated and Empty Sporocysts (Left Side) and Transepidermal Elimination of Sporangium (Right Side) (H \& E x400)

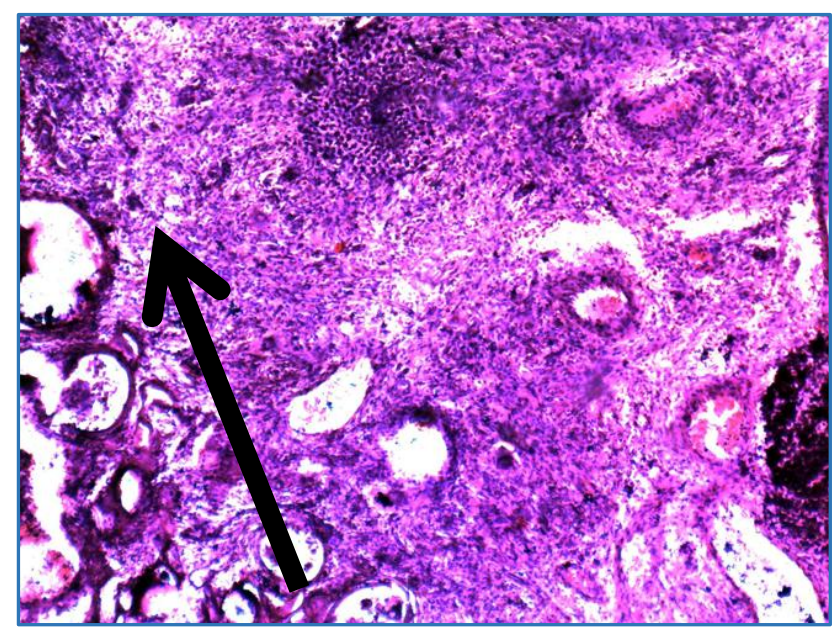

Figure 12. Microphotograph showing

Mixed Inflammatory Cell Infiltration (H \& E x100)

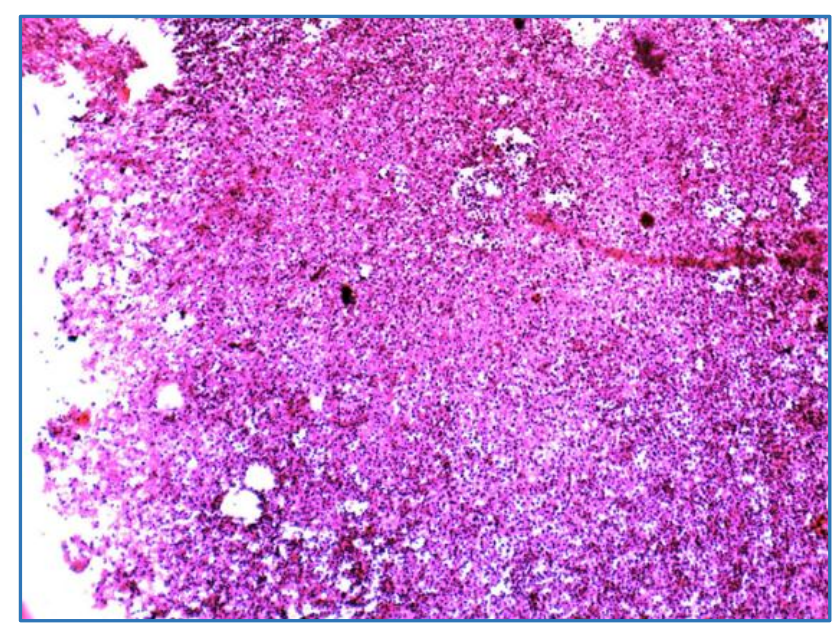

Figure 13. Microphotograph showing Microabscess (H \& E x100) 


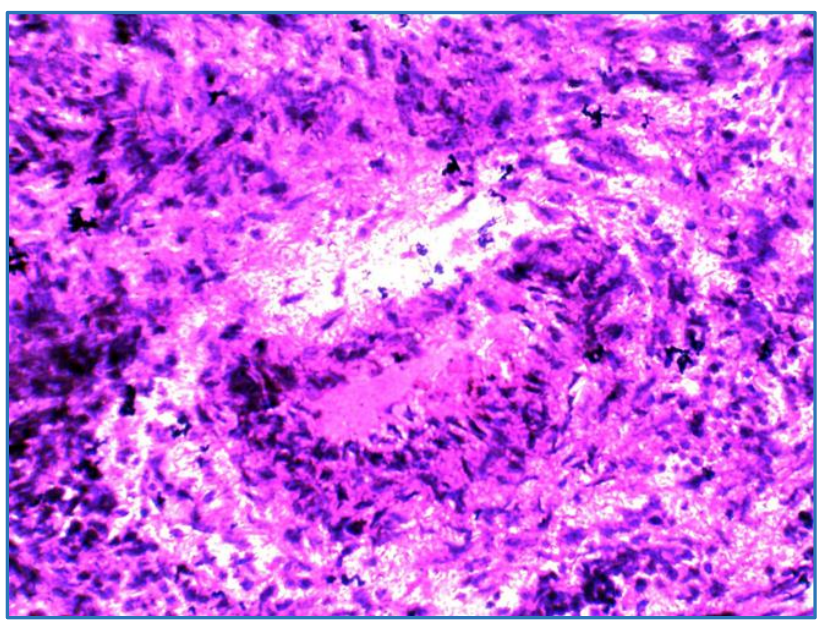

Figure 14. Microphotograph showing Granulomatous Inflammation (H \& E x400)

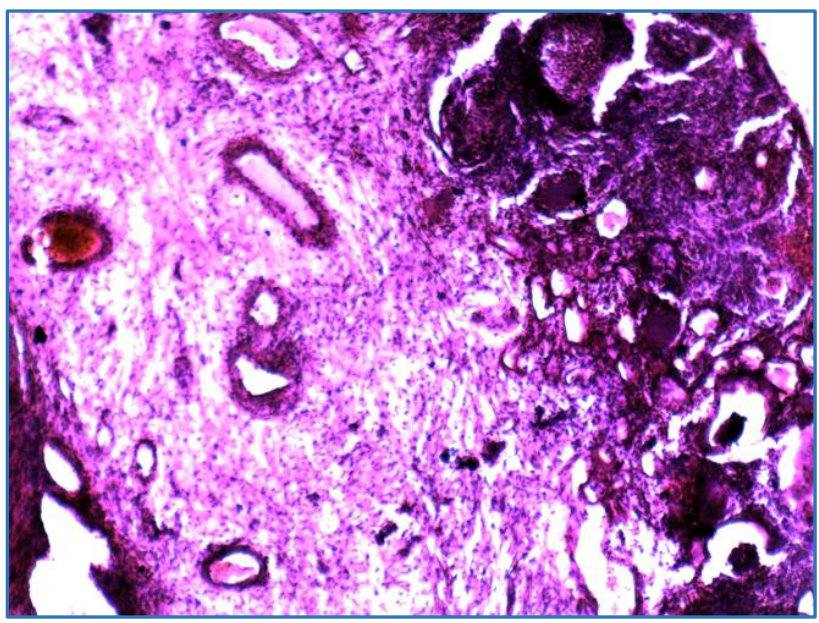

Figure 15. Microphotograph showing Stromal Oedema (H \& E x100)

\section{DISCUSSION}

The present study was carried out from the Northern 3 districts of West Bengal and adjacent two districts of Bihar. Though there are studies regarding Rhinosporidiosis from other parts of West Bengal,13,16 there is no previous study from these geographical locations. The present study indicates that diseases seen in a notable number in these regions.

Rhinosporidiosis is common in young adult (91 out of 116) with male predominance. All patients were from rural areas having history of taking bath in stagnant pond water in which cattles were also bathed regularly. These findings are similar with the studies from other parts of India.2,9,10,11,12,13,14 The ponds showed floating bamboo leaves, fallen from bamboo bush nearby the ponds.

Most of the patients were farmers followed by daily manual labourers and students from rural areas. All of the patients including rural students were exposed to dust and muddy water full of soil particles during cultivation. They used to take bath in ponds where cattle, buffaloes, etc. were taking bath regularly. The ponds showed large number of floating leaves, especially bamboo leaves fallen from the bamboo bush nearby most of the ponds.
Rhinosporidiosis is not contagious. So there is no transmission of disease among family members and between animals and human. Most probably, the contact of traumatised epithelium of nostrils with natural aquatic habitat acts as the primary mode of entry of pathogen. ${ }^{1}$ Satellite lesions occur adjacent to mass due to autoinoculation. ${ }^{2}$ In our study, two cases show skin and subcutaneous involvement of Rhinosporidiosis along with primary nasal infection. It may be due to haematogenous or lymphatic spread. ${ }^{2}$ Unfortunately, it has not yet been possible to reproduce the infection experimentally in animals as well as it has not been cultured in artificial media.1,2 Though, we have seen close association with ponds having floated leaves (especially bamboo leaves), it needs further extreme research to prove.

Tissue response developed through cell mediated immunity may be suppressed by suppressor responses.2,7,17 However, no immune deficiency has been reported with Rhinosporidiosis infection in our study.

\section{CONCLUSION}

Rhinosporidiosis is seen in a notable number in three Northern districts of West Bengal and two adjacent districts of Bihar. Majority of the patients were from young adult group with male predominance. Seven cases of ocular, three cases of oropharyngeal and two cases of skin infiltration (along with primary nasal Rhinosporidiosis) have been noted as relatively rare cases. However, the rest of the 104 cases involve the nose and nasopharynx. There is strong association with farmer and other labourers who are taking bath in stagnant ponds with muddy water as well as ponds with floating leaves, especially of bamboo trees. However, the source and reservoir of Rhinosporidium seeberi are not clearly known. Further extensive research is required to determine the association with animals and leaves floated over the ponds as well as mode of transmission and controls of the disease in human and animals.

\section{REFERENCES}

[1] Pal M. Veterinary and medical mycology. $1^{\text {st }}$ edn. Indian Council of Agricultural Research. Directorate of Information and Publications on Agriculture. New Delhi, Directorate of Information and Publications of Agriculture, Indian Council of Agricultural Research 2007:130-3.

[2] Sudarshan V, Goel NK, Gahine R, et al. Rhinosporidiosis in Raipur, Chhattisgarh: a report of 462 cases. Indian J Pathol Microbiol 2007;50(4):718-21.

[3] Allen FRWK, Dave ML. The treatment of rhinospridiosis in man based on 60 cases. Indian Med Gaz 1936;71(7):376-95.

[4] Karunaratne WAE. The pathology of rhinosporidiosis infection. J Path And Bact 1936;42(1):193-202.

[5] Arseculertne SN, Ajello L. Rhinosporidium Seeberi. In: Topley, Willson's Microbiology and Microbial infection. Vol. 4, Medical Micrology. 9th edn. Hay RJ, Ajello L. (eds.) London, Edward Arnold 1998:595-615.

[6] Herr RA, Ajello L, Taylor JW, et al. Phylogenic analysis of rhinosporidium seeberi $18 \mathrm{~S}$ small subunit rhibosomal DNA groups this pathogen among members of the protoctistan mesomycetozoa clad. J Clinical Microbiol 1999;37(9):2750-4. 
[7] Arseculertne SN. Recent advances in rhinosporidiosis and rhinospridium seeberi. Indian J Med Mricrobiol 2002;20(3):119-31.

[8] Pal M, Shimelis S, Rao PVR, et al. Rhinosporidiosis: an enigmatic pseudofungal disease of humans and animals. J Micropathol Resp 2016;54(1):49-54.

[9] Rajan RV, Vishwanathan GS, Rao AR, et al. Rhinosporidiosis-a study with report of a fatal case of systemic desemination. Indian J Surg 1955;17:269-98.

[10] Satyanarayana C. Rhinosporidiosis with a record of 255 cases. Acta Otolaryngol 1960;51:348-66.

[11] Nanda BK, Naik UP, Panda GK, et al. Rhinosporidiosis in western Orissa. JIMA 1969;53(10):489-92.

[12] Agarwal S. Rhinosporidiosis. JIMA 1966;46:442-7.

[13] Samaddar RR, Sen MK. Rhinosporidiosis in Bankura. Indian J Pathol Microbiol 1990;33(2):129-36.
[14] Arora R, Ramachandran V, Raina U, et al. Oculosporidiosis in northern India. Indian Paediatrics 2001;38(5):540-3.

[15] Nayak S, Acharjya B, Devi B, et al. Disseminated cutaneous rhinosporidiosis. Indian Journal of Dermatology Venereology and Leprology 2007;73(3):185-7.

[16] Sinha A, Phukan JP, Bandyopadhyay G, et al. Clinicopathlogical study of rhinosporidiosis with special reference to cytodiagnosis. J Cytol 2012;29(4):246-9.

[17] Chitravel V, Sundaraj T, Subramanian S, et al. Cell mediated immune response in human case of rhinosporidiosis. Sabouraudia 1981;19(2):135-42. 